\title{
Etiologi dan Patofisiologi Kardiomiopati Dilatasi
}

\author{
Putri Yeantesa ${ }^{1}$, Yerizal Karani²
}

\begin{abstract}
Abstrak
Kardiomiopati dilatasi atau dilated cardiomyopathy (DCM) adalah gangguan miokard yang didefinisikan oleh dilatasi dan gangguan fungsi sistolik ventrikel kiri, atau kedua ventrikel, tanpa adanya penyakit arteri koroner, kelainan katup, atau penyakit perikard. Kejadian DCM yang dilaporkan bervasiasi setiap tahunnya mulai dari lima hingga delapan kasus per 100.000 populasi. Kejadian sesungguhnya mungkin tidak diketahui karena tidak dilaporkan atau tidak terdeteksinya kasus DCM yang asimptomatis, yang dapat mengenai $50 \%-60 \%$ pasien. Kira-kira $50 \%$ dari kasus kardiomiopati dilatasi adalah penyakit idiopatik. Pada 20-30\% pasien selebihnya berhubungan dengan fenomena genetik, inflamasi dan imunologi seperti miokarditis; sedangkan sisanya akibat penyakit jantung iskemik, hipertensi, infeksi HIV, toksik, dan beberapa penyebab lain. Jelas sekarang bahwa tidak hanya sistem saraf simpatik dan sistem renin-angiotensin-aldosteron yang penting bagi perkembangan gagal jantung pada DCM. Autoimunitas, cacat genetik, metallomatrixproteinase, peningkatan deposisi dan degradasi kolagen, beta2-adrenoreseptor dan banyak faktor lain juga tampaknya memainkan peran penting.
\end{abstract}

Kata kunci: Kardiomiopati dilatasi, Patofisiologi, Etiologi

\begin{abstract}
Dilated cardiomyopathy (DCM) is a myocardial disorder defined by dilatation and impaired left ventricular systolic function, or both ventricles, in the absence of coronary artery disease, valve abnormalities, or pericardial disease. The reported DCM events vary every year from five to eight cases per 100,000 population. The actual event may not be known because there is no reported or undetected asymptomatic case of DCM, which can affect $50 \%-60 \%$ of patients. Approximately $50 \%$ of cases of dilated cardiomyopathy are idiopathic disease. In $20-30 \%$ the rest of the patient is associated with genetic, inflammatory and immunological phenomena such as myocarditis; while the rest are due to ischemic heart disease, hypertension, HIV infection, toxic, and several other causes. It is clear now that not only the sympathetic nervous system and the renin-angiotensin-aldosterone system are important for the development of heart failure in DCM. Autoimmunity, genetic defects, metallomatrix protein, increased deposition and degradation of collagen, beta2-adrenoreceptors and many other factors also seem to play an important role.
\end{abstract}

Keywords: Dilated cardiomyopathy, Pathophysiology, Etiology

Affiliasi penulis: 1. PPDS Kardiologi dan Kedokteran Vascular Fakultas Kedokteran UNAND/RSUP Dr. M. Djamil, Padang; 2. Bagian Kardiologi dan Kedokteran Vascular Fakultas Kedokteran UNAND/RSUP Dr. M. Djamil, Padang

Korespondensi: Jalan Perintis Kemerdekaan Padang kardiologiunand@yahoo.com Telp 075136494

\section{Pendahuluan}

Kardiomiopati dilatasi atau dilated cardiomyopathy (DCM) adalah gangguan miokard yang didefinisikan oleh dilatasi dan gangguan fungsi sistolik ventrikel kiri, atau kedua ventrikel, tanpa adanya penyakit arteri koroner, kelainan katup, atau penyakit perikard. Terdapat sejumlah penyakit jantung dan sistemik yang berbeda terkait dengan pelebaran ventrikel kiri dan gangguan kontraktilitas, tetapi pada kebanyakan pasien, tidak ada penyebab yang dapat diidentifikasi. ${ }^{1,2,3}$

Kejadian DCM yang dilaporkan bervasiasi setiap tahunnya mulai dari lima hingga delapan kasus per 100.000 populasi. Kejadian sesungguhnya mungkin tidak diketahui karena tidak dilaporkan atau tidak terdeteksinya kasus DCM yang asimptomatis, yang dapat mengenai 50\%-60\% pasien. Pada kebanyakan penelitian acak di banyak pusat mengenai gagal jantung, sekitar satu per tiga dari pasien yang dirawat merupakan noniskemik DCM.4,5 Prevalensi kejadian DCM di Amerika Serikat rata-rata 36 kasus per 100.000 populasi dan tercatat 10.000 kematian akibat DCM setiap tahunnya. ${ }^{6}$ Kira-kira $50 \%$ dari kasus kardiomiopati dilatasi adalah penyakit idiopatik. Pada 20-30\% pasien selebihnya berhubungan dengan fenomena genetik, inflamasi dan imunologi seperti miokarditis; sedangkan sisanya akibat penyakit jantung iskemik, hipertensi, infeksi HIV, toksik, dan beberapa penyebab lain. ${ }^{7,8}$

Baru-baru ini, banyak data telah muncul mengenai patogenesis rumit pada DCM. Jelas sekarang bahwa tidak hanya sistem saraf simpatik dan sistem renin-angiotensin-aldosteron yang penting bagi perkembangan gagal jantung pada DCM. Autoimunitas, cacat genetik, metallomatrixproteinase, peningkatan deposisi dan degradasi kolagen, beta2-adrenoreseptor dan banyak faktor lain juga tampaknya memainkan peran penting. ${ }^{9}$ 


\section{Pembahasan}

\section{Etiologi Dasar Untuk Kardiomiopati Dilatasi}

\section{Faktor Genetik dan Familial}

Terdapat tiga kategori utama dari mekanisme genetik yang terlibat dalam pengembangan DCM yang mengarah kepada perubahan fenotipe pada miosit jantung, yaitu mutasi gen, variasi polimorfik pada gen perubah, perubahan pengeluaran dari gen normal atau wild-type gen. Kardiomiopati dilatasi familial berhubungan dengan beberapa mutasi gen tunggal, biasanya enkoding cytoskeletal, membran nuklir, atau protein kontraktil, termasuk desmin, titin, dan troponin T. Transmisi biasanya autosomal dominan, meskipun warisan autosomal resesif dan $X$-linked juga dikenal. ${ }^{11}$ Dalam semua jenis kardiomiopati, ketika terjadi perburukan gagal jantung, ekspresi gen yang berubah dari normal, disebut wild type gen dapat ditemukan, seperti penurunan regulasi dari beta1-adrenoreseptor, gen ATPase, peningkatan regulasi atrial natriuretik peptida (ANP), angiotensin converting enzyme (ACE), tumor nekrosis faktor alfa (TNFa), endothelin, dll. ${ }^{12}$

Mekanisme genetik terakhir, yang mungkin bisa berkontribusi untuk asal-usul DCM idiopatik, berdasarkan variasi polimorfik dari gen pengubah. Keadaan ini tidak begitu langka di populasi, dan biasanya tidak menyebabkan perbedaan dalam fungsi dan dianggap normal. Namun beberapa polimorfisme ini bisa menyebabkan perbedaan dalam fungsi koding protein, yang mungkin dianggap sebagai variasi biologis, tetapi juga mungkin wadah untuk kerentanan yang lebih tinggi untuk penyakit atau respon yang berbeda terhadap pengobatan. Varian polimorfik gen yang mengkode ACE, reseptor AT1 angiotensin, beta1adrenoreseptor, beta2-adrenoreseptor, alfa1 adrenoreseptor dan endotelin jenis reseptor A diketahui mempengaruhi perjalanan penyakit kardiomiopati, serta memiliki respon yang berbeda untuk pengobatan. ${ }^{11,12}$

Faktanya adalah bahwa kelainan genetik berperan menawarkan wawasan pada fenotip secara umum. Sangat jelas bahwa predisposisi genetik dapat menjadi faktor sentral dalam berkembangnya DCM primer dan sekunder. Contoh utama adalah infeksi virus dan hipertensi, dimana dalam pemaparannya d apat mengarah kepada DCM hanya pada subpopulasi dari individu yang terkena. Predisposisi genetik merupakan hal yang penting dan mendasar terhadap variasi perjalanan penyakit DCM dan dapat berkontribusi terhadap respon terapi. ${ }^{13}$

IImu pengetahuan genetik dari DCM mengarah pada skrining genetik pada area klinis dan perkembangan dari klinis khusus pada pusat rujukan. Panduan yang diterbitkan oleh Heart Failure Society of America (HFSA) 2010 menyarankan skrining dan konseling genetik harus dipertimbangkan pada keluarga dimana DCM familial dicurigai, sebagai deteksi awal dari kardiomiopati pada anggota keluarga. ${ }^{13}$

\section{Faktor Inflamasi dan Infeksi}

Miokarditis adalah penyakit inflamasi miokardium, yang bisa merupakan penyebab idiopatik, infeksi atau autoimun dan dapat menyebabkan DCM. Miokarditis dapat diakibatkan oleh virus (atau patogen lainnya), penyakit autoimun, atau kombinasi (reaksi autoimun dirangsang oleh infeksi virus). Hal ini juga semakin menjelaskan bahwa faktor genetik juga meningkatkan risiko perkembangan penyakit jantung setelah infeksi virus. ${ }^{14}$ Telah lama diduga bahwa infeksi virus pada host yang rentan dapat menjadi penyebab langsung dari kardiomiopati dan dapat menjadi prekursor untuk terjadinya DCM. Hipotesis ini sulit untuk dibuktikan karena tantangan dalam mengkonfirmasikan infeksi virus pada individu yang terkena ditambah dengan fakta bahwa virus umum yang terlibat dalam kardiomiopati virus, yang menunjukkan tingkat positif palsu tinggi ketika virus terdeteksi pada pasien dengan gagal jantung. Limfositik miokarditis dengan atau tanpa nekrosis miosit telah dianggap temuan khas yang diperlukan untuk diagnosis, dan kriteria yang ditetapkan untuk evaluasi histologis yang disebut kriteria Dallas. Hubungan antara 


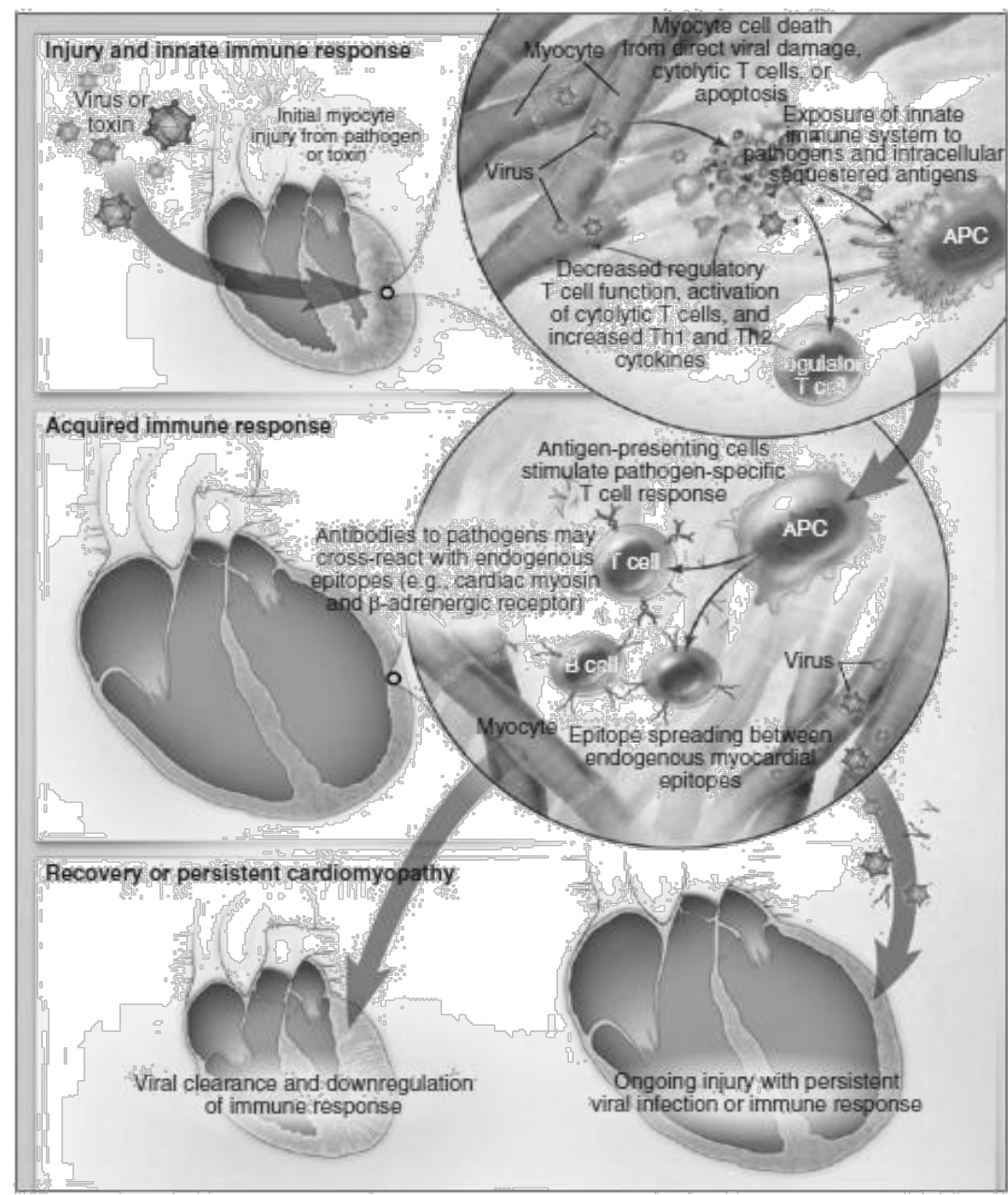

Gambar 1. Patofisiologi DCM fokus pada miokarditis ${ }^{14}$

miokarditis dan penyakit jantung akibat virus bermasalah karena inflamasi miokarditis yang sebenarnya dapat terjadi tanpa adanya agen infeksius. Penerapan polymerase chain reaction (PCR) untuk mendeteksi partikel virus dalam sampel miokard yang diambil dari pasien dengan DCM telah memberikan wawasan penting ke dalam peran yang dimainkan oleh virus penyakit otot jantung. ${ }^{11}$

Infeksi virus dapat menyebabkan miokarditis akut dan kronik. Sampai tahun 1990an, virus penyebab miokarditis yang paling banyak dilaporkan pada negara berkembang adalah adenovirus dan enterovirus. Barubaru ini parvovirus B19 (B19V) dan human herpees virus-6 banyak ditemukan dengan persentase yang signifikan pada pasien yang didiagnosa dengan kardiomiopati akut dan kronik. Dimana lebih dari 50\% dewasa muda dan lebih dari $90 \%$ orang tua telah terinfeksi oleh virus kardiotropik ini, dan hanya beberapa yang kurang beruntung yang mendapatkan sequele pada jantung. ${ }^{11}$
Dua mekanisme umum untuk cedera jantung paska infeksi virus telah ditemukan; yaitu reaksi autoimun dan cedera jaringan langsung akibat infeksi virus dari jantung (Gambar 1). Kedua mekanisme ini tidak sepenuhnya terbukti dan tetap kontroversial. Ada atau tidak adanya peradangan pada biopsi endomiokardial, yang bervariasi dari berbagai penelitian, digunakan untuk mendukung cedera imunologi. Namun, penelitian lain telah menyarankan kriteria yang berbeda (misalnya, pelengkap atau deposisi imunoglobulin). Hipotesis paska infeksi virus telah mendapat banyak dukungan, dimana material virus telah terdeteksi atas dasar peningkatan titer virus, kehadiran materi virus genom dengan PCR, dan deteksi partikel virus. ${ }^{11}$

Cooper et al menjabarkan penelitian pendukung mengenai kelainan imunitas humoral dan seluler pada DCM. Dua teori umum diusulkan untuk penyebab DCM autoimun: (1) komponen virus yang masuk ke dalam membran miosit jantung, merangsang respon antigen; dan (2) anti-jantung antibodi dihasilkan sebagai akibat 
dari kerusakan miokard. Antigen leukosit spesifik manusia (HLA) antigen kelas II (terutama DR4) berhubungan dengan DCM. Sebagai tambahan, banyak beredar antibodi antimiocardial telah dihitung pada pasien DCM yang bereaksi dengan berbagai antigen, termasuk rantai berat myosin, adrenoreseptor beta, reseptor muscarinik, sarcolemmal natrium-kalium trifosfatase adenosin, laminin, dan protein mitokondria. ${ }^{14}$

Fitur autoimun di DCM termasuk hubungan yang lemah dengan HLA-DR4 ekspresi abnormal kelas HLA II pada endotelium jantung dan peningkatan kadar peredaran sitokin dan autoantibodi jantung. Baru-baru ini,banyak penelitian telah dilakukan mengenai autoantibodi jantung pada DCM. Autoantibodi ini tidak terlalu patogenik, tetapi merupakan penanda cedera immunemediated; mereka ditemukan pada pasien dan keluarga yang beresiko, tapi tidak dalam subyek kontrol normal dan sakit, dan bereaksi dengan autoantigen unik untuk jantung. Antibodi untuk sarcolemmal dan antigen miofibrillar, untuk antigen mitokondria, seperti M7, adenosin nukleotida translocator dan enzim rantai pernapasan lainnya telah ditemukan pada pasien DCM, tetapi beberapa dari mereka bereaksi silang dengan otot skeletal, atau spesifisitas mereka untuk DCM belum benar-benar diuji. Kepentingan tertentu barubaru ini ditampilkan untuk autoantibodi terhadap beta1adrenoreseptor, terutama orang-orang yang menargetkan fungsional penting ekstraseluler loop kedua. Keadaan ini telah ditemukan dapat mengaktifkan sinyal kaskade beta1-adrenoreseptor in vitro, dan pada in vivo mereka berhubungan dengan fungsi ventrikel kiri yang lebih jelek, prevalensi yang lebih tinggi untuk terjadinya aritmia ventrikel yang serius dan insiden yang lebih tinggi dari kematian jantung mendadak. Masih belum jelas apakah DCM berkembang karena antibodi ini, atau apakah antibodi berkembang sebagai hasil cederanya jaringan jantung. ${ }^{9}$

\section{Cytotoxicity}

Aksi langsung dari berbagai faktor yang beredar terlibat dalam patofisiologi disfungsi miosit. Misalnya, tumor nekrosis faktor dan tingkat endotelin yang meningkat pada DCM. Peran yang tepat dari faktorfaktor ini tetap tidak sepenuhnya dipahami, dan terapi untuk melawan efeknya belum sepenuhnya ditemukan. Sebuah mekanisme molekuler tambahan yang mendapatkan peningkatan eksperimental dan dukungan klinis adalah ketidakseimbangan nitrosoredoks, sebuah fenomena intraseluler yang ditandai dengan disregulasi produksi nitrat oksida ditambah dengan peningkatan produksi reaktif oksigen species. ${ }^{16}$ Ketidakseimbangan ini dijelaskan dalam model hewan percobaan dan pada manusia dengan DCM dan menyebabkan disfungsi seluler dan kemungkinan sitotoksisitas. Meskipun tidak secara definitif terbukti, salah satu postulat mekanisme menjelaskan respon pasien DCM untuk hydralazine-isosorbid dinitrat adalah pemulihan keseimbangan nitroso-redoks. ${ }^{11}$

\section{Hilangnya Sel dan Keadaan Tidak Normal Dalam Mekanisme Perbaikan Endogen}

Berbagai penyebab lain terkait dengan kerusakan konstituen seluler jantung diusulkan sebagai faktor etiologi, meskipun tidak ada yang diterima sebagai penyebab mutlak. Banyak mekanisme, seperti gangguan endokrin dan eksposur beracun, berasal dari keberadaan contoh spesifik kardiomiopati sekunder. Munculnya DCM hanya sebagian kecil dari subyek dengan gangguan umum merupakan gagasan yang mendukung bahwa interaksi host(gen) dengan lingkungan tertentu menyebabkan manifestasi jantung terhadap pemaparan. ${ }^{11}$

Iskemia karena hiperaktivitas atau spasme mikrovaskulatur dapat berkontribusi untuk nekrosis miosit difus dan penggantian fibrosis. Gangguan klasik yang bermanifestasi menjadi penyakit scleroderma jantung. Peningkatan apoptosis miosit dijelaskan dalam DCM dan ARVD/C, mengarah pada saran yang menyatakan hilangnya sel dapat berkontribusi untuk remodeling ventrikel kiri dalam proses DCM. Meski begitu, terdapat peningkatan jumlah penelitian eksperimental yang mendukung pemulihan jantung ketika agen antiapoptotic diberikan pada model binatang. Peran sesungguhnya dari apoptosis dalam kondisi ini tidak diketahui. Lebih lanjut, baru-baru ini dikumpulkan data pendukung gagasan bahwa stem sel jantung endogen mengisi kembali miosit jantung sepanjang hidup, sehingga menyajikan mekanisme keseimbangan homeostasis untuk hilangnya sel dan penggantian sel setelah cedera jaringan. Beberapa penelitian sudah mendukung ide penuaan sel induk jantung yang berkontribusi untuk berkembangnya kardiomiopati pada manusia. Dengan demikian, 
penipisan atau disfungsi sel endogen dengan kapasitas untuk membagi dan membedakan pada konstituen selular jantung dapat menjadi kontributor utama patofisiologi proses kardiomiopati. ${ }^{11}$

\section{Patofisiologi kardiomiopati dilatasi}

\section{Perubahan Biologi Sel Kardiomiosit}

Perbesaran ke empat ruangan jantung merupakan tanda tipikal dari DCM (Gambar 2), walaupun terkadang penyakit ini terbatas pada sisi kanan atau kiri jantung. Ketebalan dari dinding ventrikel dapat bertambah, tapi dilatasi ruangan jantung melebihi dari proporsi seluruh hipertrofi konsentrik. Secara mikroskopik, terdapat bukti degenerasi dari miosit dengan hipertrofi yang ireguler dan atrofi dari miofiber. Fibrosis intersisial dan perivaskular sering terjadi sangat luas. ${ }^{10}$

\section{Sistem Neuroendokrin}

Perkembangan gagal jantung konsisten pada pasien dengan etiologi yang berbeda, dimana hal ini dilakukan oleh molekul aktif biologis yang sangat mirip, terlepas dari penyebab yang memicunya. ${ }^{17}$ Mekanisme kompensasi yang diaktifkan setelah penurunan kapasitas pompa jantung dapat memodulasi fungsi LV dalam kisaran fisiologis. Oleh karena itu, kapasitas fungsional pasien di awal hanya tertekan minimal. ${ }^{9}$

Aktivasi awal dari sistem saraf simpatis atau sympathetic nervous system (SNS) dan penahan airgaram renin-angiotensin-aldosteron sistem (RAAS) menjaga curah jantung dengan meningkatkan denyut jantung dan kontraktilitas dan memperluas volume plasma, dalam rangka untuk mengurangi berkembangnya tekanan hipertrofi dinding jantung, untuk mencegah vasokonstriksi berlebihan akibat

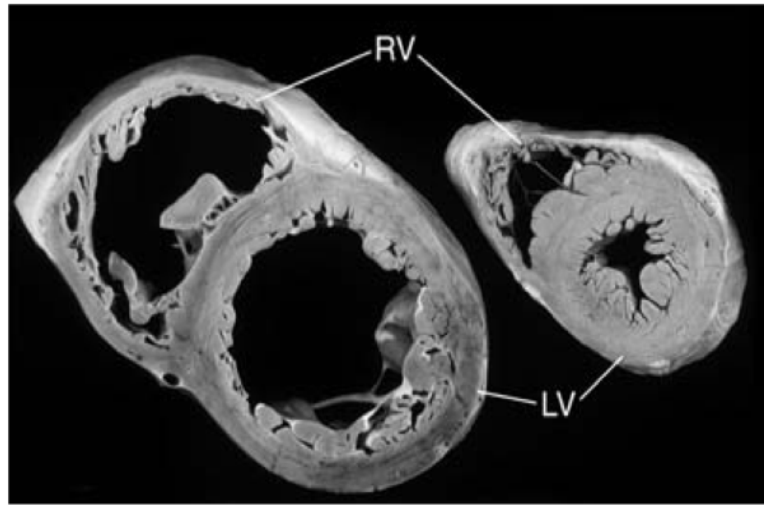

Gambar 2. Potongan melintang dari jantung normal (kanan) dan jantung dari pasien dengan DCM. Pada spesimen DCM, trdapat dilatasi buventrikular tanpa peningkatan yang proposional dari ketebalan dinding. $\mathrm{LV}$, left ventricle: $\mathrm{RV}$, right ventricle. 10

peningkatan aktivasi SNS dan RAAS, keluarga molekul vasodilatasi, termasuk peptida natriuretik, prostaglandin (PGE2,PGEI2) dan oksida nitrat, diaktifkan. ${ }^{17}$ Namun untuk waktu yang lebih lama semua mekanisme kompensasi ini menunjukkan pengaruh yang merugikan, seperti perubahan ekspresi gen, sehingga terjadi perubahan di miosit jantung, pertumbuhan, remodeling dan apoptosis (Gambar 3). Angiotensin II melalui deposisi kolagen diduga meningkatkan fibrosis miokard. Stimulasi adrenergik yang berlebihan memiliki efek toksik pada miosit dan menyebabkan nekrosis

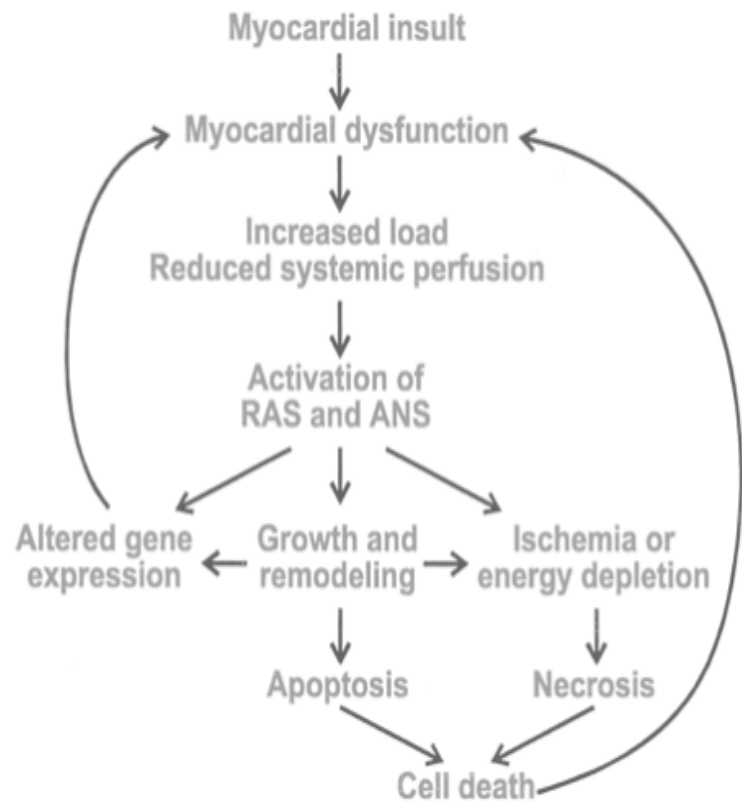

Gambar 3. Hubungan dari aktivasi neurohormonal dan kematian miosit jantung disebabkan oleh apoptosis dan nekrosis serta perubahan gen. ${ }^{9}$

miosit. Telah didokumentasikan, bahwa pada tikus transgenik pengeluaran berlebih dari beta1adrenoreseptor menyebabkan hipertrofi miosit, diikuti oleh fibrosis dan gagal jantung, sedangkan pengeluaran berlebihan dari beta2-adrenoreseptor umumnya lebih dapat ditoleransi dengan baik atau bahkan bermanfaat, meskipun juga masih kontroversial. ${ }^{9}$

\section{Perubahan Pada Tingkat Miosit}

Perubahan ekspresi gen menyebabkan cacat pada pengkodean protein atau mekanisme peraturan dan disfungsi lanjut dari kontraktil miokard. Fenomena ini dapat dibagi menjadi dua kelompok: perubahan 
intrinsik dan perubahan termodulasi dari fungsi jantung.

Fungsi instrinsik jantung berarti kontraksi dan relaksasi miokardium pada saat istirahat, yang tidak dipengaruhi oleh faktor hormonal atau neural. Fungsi jantung termodulasi dirangsang atau dihambat oleh faktor ekstrinsik (neurotransmitter, sitokin,zat autokrin / parakrin dan hormon). Hal ini sangat penting untuk menanggapi perubahan kondisi fisiologis atau rangsangan fisik. Perubahan struktur miosit jantung dapat dilihat pada gambar $4 .{ }^{18}$

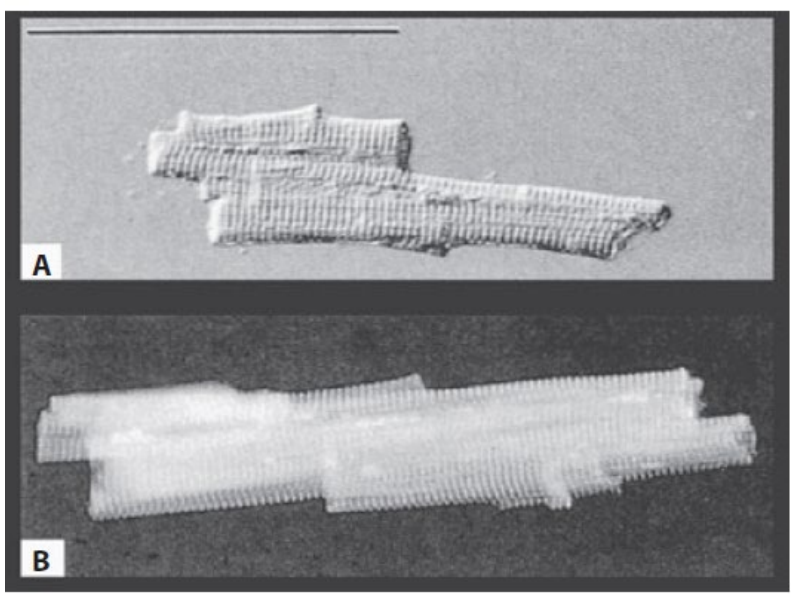

Gambar 4. Struktur miosit jantung. (A) pada miokardium normal dan pada DCM (B). Miosit jantung di pisahkan darimiokardium pada pasien dengan DCM memiliki bentuk memanjang sebagai hasil dari sarkomer yang dibentuk dalam bentuk serial ${ }^{18}$

Sebagian besar perubahan dalam modulasi fungsi jantung terjadi pada transduksi sinyal betaadrenergik. Terdapat empat jenis beta-adrenoreseptor yang telah diidentifikasi yaitu: beta-1, beta-2, beta-3 dan beta-4. Dua reseptor pertama, terutama-beta 1 penting dalam patogenesis gagal jantung. Meskipun banyak kesamaan, dua reseptor ini memiliki karakteristik genetik dan farmakologi yang berbeda. Beta1-adrenoreseptor merangsang produksi c-AMP dengan berinteraksi secara eksklusif dengan stimulator protein G, sedangkan beta2-aderenoreseptor dapat berpasangan dengan stimulator dan penghambat protein G. Selanjutnya, respon beta1-adrenoreseptor terutama terkait dengan produksi c-AMP, sedangkan beta2-adrenoreceptor lebih kompleks dan tidak didefinisikan seluruhnya. Sejumlah penelitian telah menunjukkan penurunan regulasi dari beta1adrenoreseptor pada gagal jantung dengan desensitisasi dari reseptor yang tersisa. Keadaan ini, bersama-sama dengan perubahan pada stimulasi protein $\mathrm{G}$ dan c-AMP, berefek kepada kemampuan stimulasi beta-adrenergik untuk meningkatkan denyut jantung dan mempengaruhi respon latihan dan sebaliknya pada miokard. Meskipun tingkat beta2adrenoreseptor dilaporkan tetap tidak berubah pada gagal jantung, terdapat data dimana stimulasi dari reseptor ini adalah aritmogenik, dimediasi oleh retikulum sarkoplasma atau sarcoplasmic reticulum (SR), Ca-overload induced spontaneous SR, pengeluaran $\mathrm{Ca}$ dan setelah kontraksi. Selain itu, telah disarankan bahwa pasien dengan gagal jantung dengan Thr164lle polimorfisme beta2-adrenoreseptor memiliki kapasitas latihan yang lebih rendah dan mungkin memiliki angka kematian lebih tinggi atau mengarah kepada transplantasi. ${ }^{18,19}$

Namun demikian, penghambatan dari modulasi fungsi jantung juga abnormal pada gagal jantung sebagai akibat berkurangnya pengaruh parasimpatis. ${ }^{12,18}$

\section{Perubahan Pada Tingkat Miokardium}

Pada tingkat miokard, pertama hilangnya miosit kontribusi untuk memompa disfungsi pada gagal jantung. Hilangnya miosit dapat terjadi melalui mekanisme beracun, memproduksi nekrosis, atau dengan diprogram kematian sel, memproduksi apoptosis. $^{12}$ Terdapat bukti eksperimental bahwa myonecrosis mungkin dipicu oleh peningkatan kadar peredaran norepinefrin atau norepinefrin jaringan, atau oleh stimulasi yang berlebihan dari angiotensin II atau endotelin. Selain itu, gagal jantung ditandai dengan peningkatan kematian miosit apoptosis 232-kali lipat lebih tinggi dilepaskan dari produk gen anti-apoptosis $\mathrm{Bcl}-2$ didalam sel. Hal ini telah dibuktikan dalam model in vitro dan in vivo dimana apoptosis dapat dipicu oleh beberapa faktor yang mengambil bagian dalam patogenesis gagal jantung, seperti stretch miokard, norepinefrin, TNF, stres oksidatif, angiotensin II. Namun semua penilaian saat ini tersedia dari apoptosis miosit pada gagal jantung telah dilakukan dalam jantung yang di transplantasikan dari penerima transplantasi jantung, dimana banyak dari mereka yang mendapatkan inotropik. Katekolamin juga dikenal dapat memprovokasi apoptosis, tetapi masih belum jelas apakah apoptosis hanya terjadi di stadium akhir gagal jantung atau apakah memberikan kontribusi untuk perkembangan remodeling jantung dan disfungsi sistolik. ${ }^{9,17}$ 
Peningkatan deposisi kolagen telah dilaporkan dalam stadium akhir idiopatik DCM. Setelah kematian miosit, deposisi kolagen fibril berlangsung di ekstraseluler matriks. Penggantinan fibrosis serta perivaskular fibrosis sekitar pembuluh darah intramyocardial bisa dipicu oleh angiotensin II, endotelin dan aldosteron, dan diperkirakan berkontribusi terhadap peningkatan kekakuan ventrikel yang mengurangi kepatuhan miokard dan selanjutnya mengganggu fungsinya. Perubahan orientasi kolagen serat miokard juga telah dilaporkan dalam pembentukan DCM, yang mungkin lebih penting untuk fungsi mekanik miokard dibanding jumlah absolut kolagen miokard. Penggantian bertahap kolagen tipe III dengan kolagen tipe I yang lebih kuat, terjadi pada perkembangan gagal jantung, juga memberikan kontribusi untuk pelebaran kavitas. Selain itu, peningkatan fibrosis miokard yang terdeteksi pada akhir peningkatan gadolinium pada MRI jantung memprediksi dampak buruk dari kardiomiopati noniskemik. ${ }^{12}$

Namun, meskipun deposisi kolagen meningkat, meningkat kadar plasma dari produk degradasi kolagen dilaporkan pada pasien dengan gagal jantung pada DCM sekunder. Tampaknya dalam miokardium gagalnya aktivitas enzim dari collagenolytic, dikenal sebagai peningkatan metalloproteinase (MMP). MMP adalah keluarga dari enzim Zinc-dependen, masingmasing mampu menurunkan beberapa matriks ekstraseluler (ECM) dan non-ECM substrat. Mereka terlibat dalam renovasi jaringan normal, serta kondisi patologis (metastasis tumor, arthritis, peradangan, penyakit kardiovaskular). Dari 25 MMP yang berbeda, enam disajikan dalam jantung dan bertanggung jawab untuk sebagian besar fisiologis. Peran mereka dalam perkembangan penyakit jantung dan gagal jantung kini sedang gencar diselidiki. Sebagai contoh, pengeluaran yang berlebihan dari kardiak spesifik MMP-1 dan MMP9 mengarah ke degradasi progresif dari ECM, yang menyebabkan dinding LV menipis, pelebaran dan gagal jantung. Dampaknya terhadap remodeling LV juga digambarkan oleh fakta bahwa di Framingham Heart substudi peningkatan jumlah plasma MMP-9 dikaitkan dengan dilatasi LV. Stres oksidatif, TNF dan sitokin lain dan faktor pertumbuhan peptida yang disajikan pada miokardium mampu mengaktifkan MMP. Selain itu, tingkat inhibitor jaringan endogen dari metaloproteinases terbukti menurun pada proses gagal jantung. ${ }^{20,21}$

Obat penghambat MMP telah dikembangkan. Pertama, mereka yang ditargetkan pada penyakit dengan indikasi seperti kanker dan gangguan rematologi, dan selanjutnya muncul studi hewan yang nanti dampaknya terhadap remodeling LV. Inhibitor MMP tidak selektif berhasil digunakan pada model binatang untuk remodeling LV; kemudian, inhibitor MMP selektif dikembangkan, yang berkembang dari hewan ke studi klinis. Namun, meskipun pada model binatang remodeling LV sukses, tidak ada keuntungan yang terlihat dalam studi klinis yang dilakukan. ${ }^{22,23}$

\section{Perubahan Geometri dan Arsitektur Ventrikel Kiri}

Ada dua pendapat yang berbeda tentang peran LV remodeling. Beberapa peneliti melihatnya sebagai respon end-organ stimulasi neurohormonal tahan lama dan perubahan terjadi di tingkat miokard; penelitian lain menunjukkan bahwa LV remodeling mungkin berkontribusi secara independen untuk perkembangan gagal jantung dan terutama peningkatan tekanan dinding LV. ${ }^{9}$

Peningkatan telanan akhir diastolik dinding LV terjadi sebagai hasil dari peningkatan ukuran LV dan perubahan geometri dari ellipsical ke bentuk yang lebih bulat. Mengingat bahwa beban ventrikel pada akhir diastol berkontribusi untuk afterload yang dihadapi ventrikel pada awal sistol, selanjutnya LV dilatasi meningkatkan pemanfaatan oksigen kerja. Peningkatan afterload, dibentuk oleh LV dilatasi bersama-sama dengan penipisan dinding LV yang terjadi selama remodeling, hal ini memberikan kontribusi penurunan curah jantung. Tingginya tekanan dinding pada akhir diastolik dapat menyebabkan episodik hipoperfusi dari subendokardium, dengan resultan memburuknya fungsi LV dan peningkatan stres oksidatif, dengan aktivasi yang dihasilkan gen sensitif terhadap generasi radikal bebas (misalnya TNFa dan interleukin-1 beta). ${ }^{9,17}$

Selain itu, pada ventrikel yang memanjang dan dilatasi, papiler otot ditarik terpisah, yang menghasilkan ketidakmampuan katup mitral dan pengembangan mitral regurgitasi fungsional. Hal ini menyebabkan hilangnya aliran darah keluar jantung, dan kedua aliran 
regurgitasi selanjutnya menyebabkan overload ventrikel. ${ }^{17}$

Perubahan kompleks yang terjadi di miosit miokard dan tingkat ventrikel, seperti kehilangan miosit, peregangan dan penyelipan, fibrosis yang berlebihan dan degradasi matriks ekstraseluler, mungkin mengakibatkan hilangnya pengaturan serat normal di miokardium, dan yang terakhir signifikan selama adaptasi kompleks yang berkaitan dengan transfer energi yang optimal dari miokardium ke darah pada jantung normal. Orientasi serat yang abnormal dapat berkontribusi hilangnya sinkronisitas dan homogenitas dari fungsi sistolik. Studi yang telah dipublikasikan Yildirim dkk, menunjukkan bahwa pada DCM idiopatik gerakan dinding LV tidak selalu hipokinetik seluruhnya dan heterogenitas regional fungsi ventrikel kiri selalu muncul; selain itu pasien dengan gagal jantung memiliki ketidaksinkronan intraventrikular yang lebih jelas dibanding subjek normal, yang merupakan prediktor jangka panjang independen dari kejadian penyakit jantung dan yang dapat dikurangi dengan terapi beta bloker atau terapi sinkronisasi jantung. Modalitas ekokardiografi yang baru, seperti pencitraan Doppler jaringan atau pencitraan peregangan dua dimensi, serta resonansi magnetik tomography memungkinkan evaluasi yang tepat dari sinkronisitas ventrikel. ${ }^{24,25}$

\section{Simpulan}

Sebagian besar kasus kardiomiopati dilatasi adalah penyakit idiopatik dan selebihnya berhubungan dengan fenomena genetik, inflamasi dan imunologi. Patogenesis terjadinya DCM tidak hanya melibatkan sistem saraf simpatik dan sistem renin-angiotensinaldosteron yang penting bagi perkembangan gagal jantung pada DCM, autoimunitas, cacat genetik, metallomatrixproteinases, peningkatan deposisi dan degradasi kolagen, beta2-adrenoreseptor dan banyak faktor lain juga memainkan peran penting. Patofisiologi DCM sendiri melibatkan perubahan biologi sel kardiomiosit, sistem neuroendokrin, perubahan pada tingkat miokardium, perubahan geometri dan arsitektur ventrikel kiri

\section{Daftar Pustaka}

1. Wexlaer R, Elton $\mathrm{T}$, Pleister A, Feldman D. Cardiomegaly. An Overview. Am Fam Physician. 2009;79(9):778-784
2. Johnson $\mathrm{WH}$, Moller JH . Congestive heart failure in infants and children. Pediatric Cardiology: The Essential Pocket Guide. $3^{\text {rd }}$ ed. Minneapolis, MN: Wiley-Blackwell; 2010: 315-317.

3. Lipshultz SE. Sleeper LA, Towbin JA, Lowe AM, Orav EJ, Cox GF, et al. The incidence of pediatric cardiomyopathy in two regions of the United States. N Engl J Med 2003; 348:1647-1655.

4. Richardson P, McKenna W, Bristow M, Maisch $\mathrm{B}$, Mautner B, O'Connell $\mathrm{J}$, et al. Report of the 1995 World Health Organization/International Society and Federation of Cardiology Task Force on the Definition and Classification of Cardiomyopathies. Circulation. 1996; 93:841-842

5. Hazebroek M, Dennert $N$ dan Heymans $S$. Idiopathic dilated cardiomyopathy: possible triggers and treatment strategies. Neth Heart J. 2012; 20:332-335

6. Manolio TA, Baughman $\mathrm{KL}$, Rodeheffer $\mathrm{R}$. Prevalance and etiology in idiopathic dilated cardiomyopathy (summary of a National Heart, Lung, and Blood Institute Workshop. Am J Cardiol 1992;69(17):1458-1466

7. Francone M. Role of Cardiac Magnetic Resonance in the Evaluation of Dilated Cardiomyopathy: Diagnostic Contribution and Prognostic Significance. ISRN Radiology 2014;2014:365-404.

8. Andrews RE, Fenton MJ, Ridout DA, Burch M. British Congenital Cardiac A. New-Onset Heart Failure Due To Heart Muscle Disease In Childhood: A Prospective Study In The United Kingdom And Ireland. Circulation 2008;117:79-84.

9. Jasaityte $R$ and Grabauskiene V. The Pathogenesis Of Heart Failure Due To Dilated Cardiomyopathy. Acta Medica Lituanica. 2009. 17:83-91

10. lee CT, Dec GW, Lilly LS. The Cardyomyopathies. In: Pathophysiology of Heart Disease. 5th ed. Philadelphia: Lippincott Wlliams\&Wilkins; 2008:244-60.

11. Zipes DP, Libby P, Bonow RO. Braunwald's Heart Disease. A Textbook of Cardiovascular Medicine, 8th ed. WB Saunders; 2007:1563-1570

12. Fuster V, O'Rourke RA, Walsh RA, Poole-Wilson $P$. Hurst's The Heart. 12th ed. New York, NY: McGraw-Hill; 2007:528-540

13. McCartan C, Mason R, Jayasinghe SR, Griffiths LR. Cardiomyopathy Classification: Ongoing Debate in the Genomics Era. Biochemistry Research International 2012; 12:1-10

14. Cooper LT. Myocarditis. N Engl J Med. 2009; 360:1526-38.

15. Frustaci A, Russo MA, Chimenti C. Randomized Study On The Efficacy Of Immunosuppressive Therapy In Patients With Virus-Negative Inflammatory Cardiomyopathy: The TIMIC study. Eur Heart J. 2009; 30:199-205.

16. Zimmet JM, Hare JM. Nitroso-Redox Interactions In The Cardiovascular System. Circulation. 2006. 114:1531-40.

17. Mann DL, Bristow MR. Mechanisms And Models In Heart Failure: The Biomedical Model And Beyond. Circulation 2005; 111: 2837-49

18. Bristow MR. Why Does Myocardium Fail? Insights From Basic Science. Lancet 1998; 352: 8-14.

19. Sata M, Sugiura S, Yamashita H, Momomura S, Serizawa T. Coupling Between Myosin ATLASE Cycle And Ceratine Kinase Cycel Facilitates 
Cardiac Actomyosin Sliding In Vitro: A Clue To Mechanical Dysfunction During Myocardial Ischemia. Circulation 1996; 93: 310-7.

20. Sundstrom J, Evans JC, Benjamin EJ, Levy D, Larson MG, Sawyer DB, et al. Relations Of Plasma Matrix Metalloproteinase-9 To Clinical Cardiovascular Risk Factors And Echocardiographic Left Ventricular Measures: The Framingham Heart Study. Circulation 2004; 109: 2850-6.

21. Peterson JT, Hallak H, Johnson L, Li H, O'Brien PM, Sliskovic DR, et al. Matrix Metalloproteinase Inhibition Attenuates Left Ventricular Remodeling And Dysfunction In A Rat Model Of Progressive Heart Failure. Circulation 2001; 103: 2303-9.

22. Spinale FG. Myocardial Matrix Remodeling And The Matrix Metalloproteinases: Influence On Cardiac Form And Function. Physiol Rev 2007; 87: 1285-342.

23. Hudson MP, Armstrong PW, Ruzyllo W, Brum J, Cusmano L, Krzeski P, et al. Effects Of Selective Matrix Metalloproteinase Inhibitor (PG-116800) To Prevent Ventricular Remodelling Aft Er Myocardial Infarction: Results of the PREMIER (Prevention of Myocardial Infarction Early Remodelling) atrial. J Am Soc Cardiol 2006; 48: 15-20.

24. $\mathrm{Yu} C M$, Lin $H$, Zhang $Q$, Sanderson JE. High Prevalence Of Left Ventricular Systolic And Diastolic Asynchrony In Patients With Congestive Heart Failure And Normal QRS Duration. Heart 2003; 89: 54-60.

25. Yildirim A, Soylu O, Dagdeviren B, Zor U, Tezel T. Correlation between Doppler derived dP / dT and left ventricular asynchrony in patients with dilated cardiomyopathy: a combined study using strain rate imaging and conventional doppler echocardiography. Echocardiography 2007; 24 :508-14 